\title{
WOKÓŁ FUNDEMENTALIZMU. ZYGMUNT BAUMAN W POZNANIU
}

Prof. Zygmunt Bauman: Ważne sprawy - a nie ulega przecież kwestii, że fundamentalizm jest dziś jedną ze spraw najważniejszych - wymagają dogłębnych i rozbudowanych argumentów. Dogłębne, rozbudowane argumenty wymagają czasu, a czas to deficytowy materiał, którego brak nam wyraźnie w tej chwili. Jestem pełen podziwu dla moich przedmówców: ile zdołali oni wtłoczyć treści $\mathrm{w}$ te parę minut, które im dano, żeby ten temat poruszyć. Po tym, co powiedzieli, niewiele mam właściwie do dodania... Tyle, że zdaję sobie sprawę, że nasze tu wypowiedzi są raczej podtytułami nienapisanych akapitów; za każdym zdaniem tu powiedzianym kryje się masa przemyśleń i parę co najmniej stron nienapisanego, a czekającego na napisanie traktatu. Więc i ja się ograniczę do jeszcze paru podtytułów do wołających o spisanie akapitów...

Zacznę od tego, że już posługując się pojęciem „zsekularyzowanego fundamentalizmu", czyli opatrując ideę fundamentalizmu kwalifikatorem, przemycamy myśl, że mowa tu nie o fundamentalizmie oryginalnym, w domyśle już znanym i nie wymagającym ponownej wykładni, ale że mamy do czynienia z (jak to się w dzisiejszym języku polskim mówi) „zrecyklowaną" formą fundamentalizmu. Nie inaczej będzie w tym, co powiedzieć tu zamierzam. Przypomnę państwu, że Leszek Kołakowski, który bardzo wnikliwie i obsesyjnie niemal zajmował się rolą religii $\mathrm{w}$ kulturze wszelkich czasów, włącznie z naszym, wywodził Boga z projekcji ludzkiej niesamowystarczalności; Bóg jest nam niezbędny wtedy, kiedy czujemy się nie na miarę wyzwań, niesamowystarczalni, brak nam pewności siebie, ani z pojmowaniem świata, ani ze z-nim-się-borykaniem nie dajemy sobie rady, a podejrzewamy że żaden ludzki rozum i moc ludzka rady sobie z nimi dać nie mogą. A z owego "nie-dawania sobie rady" zdajemy sobie sprawę najdotkliwiej nie wtedy, gdy trzeba podporządkować się nakazom/regułom/dyktatom świata (przyrodniczego czy ludzkiego), bo to jakby Heidegger powiedział zuhanden, przesłonięte światłem, zbyt pospolite 
by je zauważyć - ale gdy trzeba się z nich wyłamać czy je obejść... Bóg, proszę państwa, jest nam głównie potrzebny nie do przestrzegania praw, nagradzania tych co im się podporządkowują i karania tych, którzy je łamią, ale do stanowienia wyjątków i czynienia cudów, i w ogóle odstępstw od żelaznych reguł - i to $\mathrm{w}$ dwu zasadniczych dla życia dziedzinach: mocy rozumienia i mocy czynu (sprawiania, by coś nie stało, lub zapobiegania temu, by się stało).

Krótko mówiąc: postrzeganie niesamowystarczalności bierze się z poczucia: a) ignorancji; b) impotencji, a gdy do ignorancji dorzucić impotencję, produktem chemicznej reakcji będzie upokorzenie, cios zadany godności własnej i uwłaczający szacunkowi dla siebie - słowem, nieznośny stan psychiczny, wołający o ratunek czy może o pomstę, co zresztą nierzadko na jedno wychodzi. Fundamentalizm kusi i uwodzi obietnicą jednego i drugiego naraz.

Zaczął fundamentalizm od przybrania szaty religijnej... Profesor Kubicki słusznie powiązał jego narodziny ze zmaganiem postawy platońskiej z sofistyczną, i słusznie zauważył, że jakieś wcielenie tej kontrowersji, jakaś odmiana platonizmu i usposobienia sofistycznego obecne były w każdej epoce. Zgoda - ale zwróciłbym też uwagę na inną podobnie ponadczasową opozycję między światopoglądami i między strategiami dla kwestii fundamentalizmu zasadniczą - a mianowicie między monoteizmem a politeizmem.

Idąc do źródła powiedziałbym: odwiecznie toczący się spór i współdziałanie konfliktem nasączone między Jerozolimą a Atenami: Jerozolimą, gdzie się zrodził Bóg Jedyny, który ogłosił wszystkich innych bogów bogami fałszywymi, złudami spreparowanymi przez siły nikczemne czy niecnymi samozwańcami, a Atenami z ich zatłoczonym Olimpem, i bogiem, a niekiedy i paroma na każdą okazję i każdą porę roku i dnia. Imperium Rzymskie zajęte podbojem świata wyciągnęło z nauk greckich właściwe wnioski i z przyłączeniem każdego nowego kraju nadawało miejscowej ludności prawa obywatelskie, a jej bogom godziwe miejsce w rzymskim Panteonie - dusząc $\mathrm{w}$ zarodku reakcje fundamentalistyczne (tylko z Jerozolimą, co to jednego-jedynego Boga wymyśliła, ta sztuczka się nie powiodła)...

Ale fundamentalizm jest dziecięciem nie tylko religii monoteistycznej, ale wszelkiego monoteizmu czy monologizmu, którego religia jest jednym z przypadków: układu, w jakim obowiązuje jedna prawda i jeden kodeks, a priori i a limine, wyłączając możliwość innych prawd i kodeksów. Zresztą Jahve był chyba jeszcze przynajmniej potencjalnie politeistą - dopiero Elohim zażądał monoteistycznego monopolu. Pomyślcie państwo o tych dwóch Bogach biblijnych - tego co wypędza Adama i Ewę z raju i tego 
z góry Synaj i Księgi Kapłanów, który wyłuszcza w najdrobniejszych szczegółach, nie pozostawiając miejsca na dylematy i wybory, przepisy na każdą życiową okazję, łącznie z takimi przepisami jak np. jaką rekompensatę winniśmy sąsiadowi, jeśli pożyczony nam przezeń wół straci oko albo okuleje (Bóg, który wyganiał Adama i Ewę z raju, udzielił tylko dwu wskazówek: Adamowi powiedział, że będzie zdobywał chleb w pocie czoła, a Ewie, że będzie rodziła w bólach. Gdzie tam takim wskazówkom do fundamentalizmu, który rości sobie pretensje do zglajchszaltowania całości życia!) Bóg rajski skazał człowieka na wolność, Synajski na niewolę. Potem jednak drobiazgowy kodeks nadbudowano księgą Hioba, z której jak to Kołakowski pięknie a niezbicie wyłożył, wynika że Bóg nie jest niczego ludziom winny, nawet jeśli ułożony przez Niego kodeks wykuli na pamięć i się do niego niezachwianie stosują. No, ale skoro tak, to kontrakt synajski jedną tylko stronę obowiązywał do konsekwencji, gdy niekonsekwencję uczynił atrybutem bożym. Tu pojawia się $\mathrm{w}$ fundamentalizmie pęknięcie, sprzeczność wewnętrzna, a wszak niezbędna, bo bez niej straciłby aurę puklerza chroniącego przed rutynowym okrucieństwem świata. Żeby tę aurę posiadał i zachował na przekór testom doświadczenia, Bóg musi być zdolny nie do narzucania praw, lecz do czynienia wyjątków - „cudów”... Potęga Boga tkwi w czynieniu miejsca na możliwość rzeczy i zajść niemożliwych, na stawanie się rzeczy niespodziewanych, niewytłumaczalnych, niezrozumiałych - a upragnionych... Leon Szestow rozciągał władzę Boga nawet na rzeczy już zaszłe, na przeszłość: Bóg może sprawić, twierdził, że Sokratesowi nigdy cykuty wypić nie kazano...

Czy w dzisiejszych fundamentalizmach, jak wszelkie fundamentalizmy oferujących nadludzkie lekarstwa na ludzkie dolegliwości i ufność w Boga jako lekarstwo na ból sprawiany brakiem ufności we własne siły, jest jednak coś nowego, czego nie było w poprzednich wiekach? Chciałbym zasugerować państwu, że ten nasz nowy fundamentalizm wynika $\mathrm{z}$ innego nieco gatunku ludzkich kłopotów w warunkach nowoczesnych, których początek zbiegł się przecież ze stwierdzeniem, że Deus jest absconditus, że po stworzeniu świata i wypuszczeniu Adama i Ewy w świat na ich własne ryzyko wycofał się On z mieszania się w ich codzienne sprawy. W XVII-XVIII stuleciach, a już szczególnie wyraźnie po katastrofie lizbońskiej, nie dającej się pogodzić z tym co teologowie głosili o wszechmocy i wszechdobroci Boga, postanowiono wziąć świat pod zarząd ludzki, licząc na to, że rozum ludzki, z natury swojej skłonny, a raczej przymuszony do logicznego postępowania, potrafi rękoma oświeconych despotów czy wybranych demokratycznie przywódców, albo rękoma każdego z nas i wszystkich nas razem, zaprowadzić na ziemi ład, czego Bóg, ze swą nadludzką zdolnością czynienia wyjątków i cudów z własnej decyzji z której się nie zwierza, decyzji niewy- 
tłumaczalnej, niewyjaśnialnej (jego umysłu przecież, ani motywów, przeniknąć nie możemy) - nie dokonał.

Ale przejęcie wszechświata pod zarząd ludzki zaowocowało nowymi mękami ignorancji i bezsiły wraz z ich nieuchronnymi następstwami - nieznośnym upokorzeniem i stratą pewności siebie: $\mathrm{z}$ doskwierającym boleśnie poczuciem niesamowystarczalności, lecz tym razem ciążącej nie na losie gatunku ludzkiego jako całości, lecz na barkach jednostki. Nieustępliwa indywidualizacja, towarzysząca emancypacji jednostki spod kurateli przedustawnego ładu ucieleśnionego w równie przedustawnych chyba, bo wszak opornych na ząb czasu zbiowościach ludzkich (plemionach, stanach, kościołach, narodach), uczyniła z wszystkich istot ludzkich indywidua de iure, ze zrządzenia losu i/lub na mocy dekretu, stawiając ich tym samym przed zadaniem wyniesienia się, własną mocą i staraniem, do rangi indywiduów de facto, czyli samookreślających się, samoustanawiających i samoutwierdzających podmiotów: zadaniem ponad ludzkie siły, przerastającym potencje większości jednostek, brzemiennym porażką, a przynajmniej jej podejrzeniem. Jak to ujął Ulrich Beck, na każdym i każdej z nas spoczywa dziś powinność znalezienia indywidualnych sposobów na rozwiązywanie społecznie wytwarzanych problemów - i to za pomocą własnej wiedzy, narzędzi i wysiłków. Szkopuł w tym, że większości jednostek brak i wiedzy i narzędzi, a może i samozaparcia, jakich spełnienie tej powinności wymaga. I $\mathrm{z}$ tej to niemocy rodzi się fundamentalizm najnowszego, płynnienowoczesnego chowu.

Dzisiejszy fundamentalizm jest nie tyle ucieczką przed przerażającą nieprzenikliwością świata, ile przed koniecznością zmagania się z jej następstwami w pojedynkę. Pokusa fundamentalizmu zbrojna jest dziś obietnicą schronienia przed widmem samotności, pozostawienia samemu sobie, bycia rzuconym na łaskę nieadekwatnych, wyraźnie niedostatecznych zasobów, środków, talentów, jakim zaufać nie mamy podstaw i na które nie możemy liczyć, że przypisanemu im zadaniu sprostają. Ale zauważmy z miejsca. Że ucieczka w fundamentalizm nie jest przez ową „samotność w tłumie" jednoznacznie zdeterminowana. Są wszak środki zastępcze, gorliwie przez przemysł konsumpcyjny produkowane i na rynek konsumpcyjny rzucane, a obiecujące zaspokojenie tejże potrzeby, której zaspokojenie fundamentalizm zapowiada - ale nadto z poszanowaniem jednostkowej wolności, bez jej składania na ołtarzu surowych wymogów bezwzględnej dyscypliny, z jakich rozwiązania fundamentalistyczne są znane.

Pierwszą bodaj z tych namiastek, nacelowanych na ten sam rodzaj zapotrzebowania co oferta fundamentalistyczna, był walkman, wprowadzany na rynek pod hasłem: nigdy więcej samotności (Never again alone). Hasło chwyciło, miliony się $\mathrm{w}$ magiczny środek profilaktyczny przeciw samotno- 
ści zaopatrzyły. Dziś, po upływie paru zaledwie dziesiątków lat, Walkman przypomina swych następców - komórkę, facebooka, myspace's czy twittera, jak topór z epoki kamienia łupanego boschową piłę łańcuchową, a krzemień i hubka palnik gazowy zapalający się za naciśnięciem guzika choć w każdym z przytoczonych tu na chybił-trafił casusów potrzeby jakim narzędzia miały służyć pozostały niezmienione.

W naszym świecie zaludnionym przez Männer ohne Verwandschaften, potrzebą o jakiej zaspokojenie neo-fundamentalistyczne ruchy współzawodniczą z elektronicznymi gadżetami od Walkmana po twittera jest wypełnienie luki pozostawionej przez uwiąd wspólnotowych więzi. Jeśli się postarać, można sobie w jednym dniu zafundować „wirtualną wspólnotę" 500 albo i więcej "przyjaciół”. I lepsza to mówiąc szczerze wspólnota, bo o ileż mniej krępująca od tej, którą chce się zastąpić, a którą fundamentalizm chce wskrzesić w tejże co dawna postaci. Choć sprawa daleka jest od jednoznaczności, i szale się wahają. No bo za łatwość podłączania się i odłączania „wspólnoty” elektroniczne płacą chrupkością i niespolegliwością. Ta „wspólnota" nie siedzi wprawdzie na karku ani bicza do zapędzania do szeregu nie używa, ale za to nie można być pewnym, że pospieszy z pomocą $\mathrm{w}$ potrzebie. Od wymagań stawianych przez „przyjaciół” z facebooka można się wykpić bez trudu i wstydu, ale też i nie wiadomo, czy pozna się ich $\mathrm{w}$ biedzie... $\mathrm{W}$ tej tu konkurencji fundamentalizm $\mathrm{z}$ jego regularnymi pospólnymi obrzędami i wymogiem dozgonnej wierności i posłuszeństwa wygrywa, by tak rzec, w przedbiegach... Odwołuje się on wszak do tego, co (jeśli wierzyć Michelowi de Montaigne) Étienne de La Boétie już u progu nowoczesnej ery opisał jako przyrodzony ludziom pociąg do „dobrowolnego zniewolenia" - zdjęcia z siebie odpowiedzialności za porażki, choćby i za cenę rezygnacji z poniektórych sukcesów.

Wolność indywidualna przychodzi wraz z odpowiedzialnościa indywidualną, odpowiedzialność indywidualna przychodzi ramię $\mathrm{w}$ ramię z ryzykiem indywidualnej porażki i koniecznością przyjęcia za nią winy. To od tych niedłącznych kompanów wolności fundamentalizm zwolnić obiecuje. Do strachów by tak rzec gatunkowych dołączyła w naszych czasach obawa samotników. Do odwiecznych poszukiwań schronienia przed ignorancją i impotencją gatunku ludzkiego doszlusowała dojmująca potrzeba ratunku przed osobistą odpowiedzialnością za osobistą klęskę: przed niespełnieniem oczekiwań jakich $\mathrm{w}$ pojedynkę spełnić się nie da, przed potępieniem, odtrąceniem i banicją. Prędzej czy później, stając oko w oko z oczekiwaniami, przed jakimi teraz jako jednostki jesteśmy stawiani, dojść możemy do wniosku, że to ponad nasze siły, że siła złego na jednego, że nie potrafimy tego zrobić - a owe władze „tam na górze”, jakie miały niegdyś spieszyć nam z pomocą, nie tylko do pomocy się nie kwapią, ale jeszcze dorzucają 
nam zadań do indywidualnego rozwiązywania, choć i pod poprzednimi plecy nam się porządnie ugięły. Głoszona ostatnio przez nowe władze angielskie idea "wielkiego społeczeństwa” na tym właśnie w ostatecznym rachunku polega, że każdy członek społeczeństwa sam na własną rękę będzie mógł się podejmować rozwiązywania problemów, których państwo dobrodusznie na jego rzecz się zrzeka. Nielogiczne to może, ale całkiem nieprzypadkowe, że ogłoszenie „wielkiego społeczeństwa” zbiegło się z obcięciem kilkunastu miliardów funtów z budżetu dofinansowywania lokalnych społeczności i organizacji „społeczeństwa obywatelskiego”. Fundamentalizmom, świeckim czy nie-świeckim, w to im graj... 